\title{
Sequential evolution of IL-17 responses in the early period of allograft rejection
}

\author{
Sang II Min ${ }^{1}$, Jongwon $\mathrm{Ha}^{1,4}$, Chung-Gyu Park ${ }^{2,4}$, \\ Jae Kyung Won ${ }^{3}$, Yang Jin Park ${ }^{1}$, Seung-Kee Min ${ }^{1}$ \\ and Sang Joon $\mathrm{Kim}^{1,4,5}$

\section{${ }^{1}$ Department of Surgery} \\ ${ }^{2}$ Department of Microbiology and Immunology \\ Cancer Research Institute \\ ${ }^{3}$ Department of Pathology \\ Seoul National University College of Medicine \\ Seoul 110-799, Korea \\ ${ }^{4}$ Transplantation Research Institute \\ Seoul National University Medical Research Center \\ Seoul 110-799, Korea \\ ${ }^{5}$ Corresponding author: Tel, 82-2-2072-3308; \\ Fax, 82-2-745-2883; E-mail, sjkimgs@ @nu.ac.kr \\ DOI 10.3858/emm.2009.41.10.077
}

Accepted 26 May 2009

Abbreviations: CMN, coagulative myocyte necrosis; IACUC, institutional animal care and use committee; ISHLT, International Society for Heart and Lung Transplantation; Th cell, helper T cell; $T_{\text {reg }}$ cell, regulatory $T$ cell

\begin{abstract}
In addition to $\mathrm{CD} 4^{+} \mathrm{CD} 25^{+} \mathrm{Foxp}^{+}$regulatory $\mathrm{T}$ (Treg) cells which protect against autoimmune tissue injury, IL-17-producing $\mathrm{CD}^{+} \mathrm{T}\left(\mathrm{T}_{\mathrm{h}} 17\right)$ cells have been recently described and shown to play a crucial role in autoimmune injury. It appears that there is a reciprocal developmental pathway between $T_{h} 17$ and Treg cells. Although IL-17 is known to be associated with allograft rejection, the cellular source of IL-17 and the nature of Th17 in the context of allograft rejection remain unknown. In the current study, the dynamics of Treg and IL-17-producing cells after syngeneic and allogeneic transplantation were examined using a wild-type murine cardiac transplantation model. Ly6G ${ }^{+}$cells were found to produce IL-17 during the early postoperative period and $\mathrm{CDB}^{+}$as well as $\mathrm{CD4}{ }^{+} \mathrm{T}$ cells were also found to produce IL-17 during alloimmune response. Graft-infiltrating $\mathrm{Ly} 6 \mathrm{G}^{+}, \mathrm{CD}^{+}$, and even $\mathrm{CD8}^{+}$cells were found to express IL-17 highly compared to those in spleen. Although the frequencies of Th17 and Treg were found to gradually increase in both syngeneic and allogeneic recipients, $\mathrm{Th}_{\mathrm{h}} 17 / \mathrm{T}_{\mathrm{reg}}$ ratios were signi-
\end{abstract}

ficantly higher in recipients with allograft rejection than in syngeneic recipients. In conclusion, IL-17 is produced by neutrophils during the early postoperative period and subsequently by $\mathrm{Th}_{\mathrm{h}} 17$ and $\mathrm{CD} 8^{+}$ $T$ cells during allograft rejection. $T_{h} 17 / T_{\text {reg imbalance }}$ is associated with the development of allograft rejection. This study would provide basic information on $\mathrm{Th}_{\mathrm{h}} 1 \mathrm{biology}$ for future investigation in the field of transplantation.

Keywords: graft rejection; interleukin-17; neutrophils; T-lymphocytes, regulatory

\section{Introduction}

$\mathrm{CD}^{+}{ }^{+}$helper $\mathrm{T}$ cells proliferate and differentiate into effector T cell subsets with specific cytokine phenotypes in response to antigen-specific activation. $T$ helper $\left(T_{h}\right)$ cells are traditionally classified as $T_{h} 1$ and Th2 cells based on their cytokine-expression profiles (Mosmann et al., 1989). In particular, Th1 cells produce IFN- $\gamma$, which enhances cellular immunity and is required for the clearance of intracellular organisms. On the other hand, Th2 cells produce IL-4, IL-5, IL-13 and IL-25, which enhance humoral immunity and are important for $\lg \mathrm{E}$ production, eosinophilic inflammation, and the elimination of helminthic infections (Abbas et al., 1996). However, recent murine experiments have changed this $\mathrm{Th} 1 / \mathrm{Th} 2$ paradigm by demonstrating that $\mathrm{CD}^{+} \mathrm{Th}$ cells can differentiate into $\mathrm{Th} 17$ cells, which produce IL-17 and play a crucial role in inflammation and autoimmune diseases (Aggarwal et al., 2003; Cua et al., 2003; Langrish et al., 2005). In addition, $\mathrm{CD} 4^{+} \mathrm{CD} 25^{+} \mathrm{Foxp} 3^{+}$regulatory $\mathrm{T}$ ( $T$ reg) cells have also been described as a distinct subset from $\mathrm{Th} 1$ and $\mathrm{Th} 2$ cells. Treg cells play an anti-inflammatory role and maintain tolerance to self-components by contact-dependent suppression or by releasing anti-inflammatory cytokines, such as, IL-10 and TGF- $\beta$ ( $\mathrm{Ng}$ et al., 2001; Dieckmann et al., 2002; Fontenot et al., 2003; Sakaguchi et al., 2006). Furthermore, the productions of $\mathrm{Th} 17$ and Treg cells appear to be mutually exclusive (Bettelli et al., 2006; Mucida et al., 2007) and therefore, the balance between Treg and Th17 cells may be important during the development of autoimmune diseases (Homey, 2006).

Recent studies have established that IL-17 re- 
leased by Th17 cells plays key roles during the pathogenesis of experimental autoimmune encephalitis (Langrish et al., 2005), rheumatoid arthritis (Kotake, 1999; Cho et al., 2008), inflammatory bowel disease (Fujino et al., 2003), psoriasis (Zheng et al., 2007) and uveitis (Amadi-Obi et al., 2007). However, the role of Th17 and its archetypal cytokine, IL-17, is unclear in transplantation immunity. Some studies have shown that IL-17 is associated with acute allograft rejection. In a rat renal allograft transplantation model, IL-17 mRNA levels were found to peak on postoperative day 5 , and then decline (Loong et al., 2002). Furthermore, the acute rejection of aortic allografts was prevented and cardiac allograft survival was prolonged by neutralizing IL-17 with an IL-17R:IgG-Fc fusion
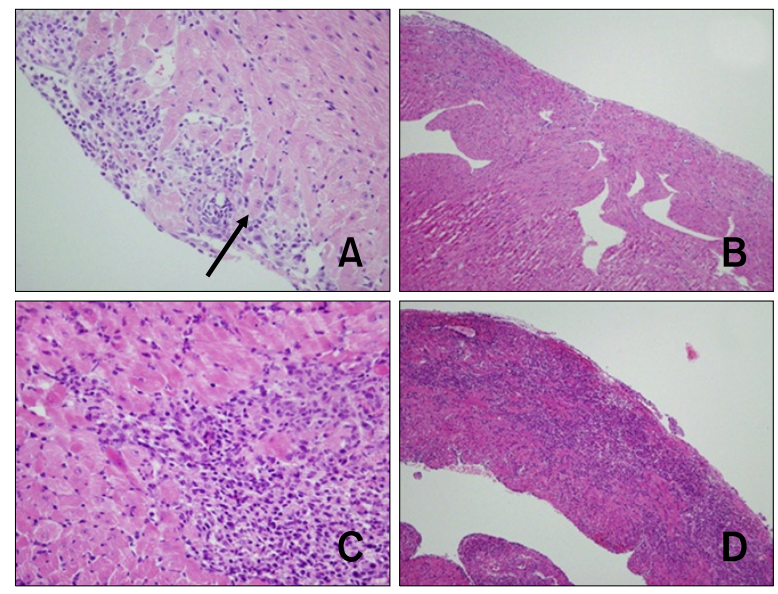

\section{E}

\begin{tabular}{|c|c|c|c|}
\hline $\begin{array}{c}\text { Days after } \\
\text { transplantation }\end{array}$ & $\begin{array}{c}\text { Group } \\
(\mathrm{N})\end{array}$ & $\begin{array}{c}\mathrm{CMN} \\
(\text { Grade) }\end{array}$ & $\begin{array}{c}\text { Rejection } \\
\text { (Grade) }\end{array}$ \\
\hline \multirow{2}{*}{1} & Syngeneic (5) & 1 & 0 \\
& Allogenic (5) & 1 & 0 \\
\hline \multirow{2}{*}{3} & Syngeneic (6) & 2 & 0 \\
& Allogenic (5) & 2 & $1 \mathrm{R}$ \\
\hline \multirow{2}{*}{5} & Syngeneic (4) & 1 & 0 \\
& Allogenic (4) & 1 & $2 \mathrm{R}$ \\
\hline
\end{tabular}

Figure 1. Histopathologic examination of syngeneic and allogeneic murine cardiac transplants. Tissue sections were stained with H\&E. (A) Syngeneic graft in a B6 recipient showing predominant neutrophil infiltration and Grade 2 multifocal coagulative myocyte necrosis (CMN; arrow) on the $3^{\text {rd }}$ postoperative day $(\times 400)$. (B) Syngeneic graft in a B6 recipient showing an improved inflammatory response with little leukocyte infiltration on the $5^{\text {th }}$ postoperative day $(\times 100)$. (C) BALB/C allograft in B6 recipient showing characteristic mononuclear cell infiltration and Grade $1 \mathrm{R}$ acute cellular rejection (ACR) on the 3rd postoperative day $(\times 400)$. (D) BALB/C allograft in B6 recipient showing Grade $2 R$ rejection on the $5^{\text {th }}$ postoperative day $(\times 100)$. (E) Summary of histopathological features. Histopathology of these grafts (A-D) shows the grade of ACR deteriorated with time in allogeneic grafts and the extent of CMN was peaked on day 3 in both groups. protein (Tang et al., 2001; Li et al., 2006). Although these data may suggest that $\mathrm{Th} 17$ cells potentially impact acute allograft rejection, the cellular source of IL-17, and the nature of Th17 cells during allograft rejection remain unknown.

Accordingly, we first analyzed the dynamic differentiations of $T_{r e g}, T_{h} 17$, and other $\mathrm{IL}-17^{+}$cells, including neutrophils and $\mathrm{CD}^{+} \mathrm{T}$ cells, in the context of murine cardiac transplantations. We then evaluated the significances of $\mathrm{Th} 17 / \mathrm{T}_{\mathrm{reg}}$ balance during allograft rejection.

\section{Results}

\section{Histopathological changes}

The extent of coagulative myocyte necrosis (CMN), the most definitive characteristic of ischemic heart injury, was diagnosed in both groups of syngeneic and allogeneic recipients as grade 2 at 3 days and grade 1 at 5 days after transplantation (Figure $1 \mathrm{~A}$ and $1 \mathrm{~B}$ ). Furthermore, regardless of transplantation group, at day 3 , sections of cardiac grafts showed predominant neutrophil infiltration, regarded as archetypal cells of ischemic reperfusion injury. The grade of acute cellular rejection (ACR) deteriorated with time; grade $1 \mathrm{R}$ at day 3 and grade $2 \mathrm{R}$ at day 5 after transplantation (Figure $1 \mathrm{C}$ and 1D). Sections of allografts showed characteristic mononuclear cell infiltration during acute cellular rejection. Complete rejection of cardiac allografts occurred at $7.8 \pm 0.12$ days after transplantation. Histopathological features of cardiac graft recipients were summarized in Figure $1 \mathrm{E}$.

\section{Serial changes in serum levels of cytokines}

Serum levels of IL-17 and IFN- $\gamma$ were quantitated using Bio-Plex ${ }^{\mathbb{R}}$ kits in untransplanted control B6 mice (day 0 ), allogeneic (BALB/C $\rightarrow$ B6) recipients, and syngeneic (B6 $\rightarrow \mathrm{B} 6$ ) recipients on days 1,3 , and 5 after transplantation (Figure 2). To determine whether increased production of IL-17 after cardiac transplantation is alloantigen-specific, we initially evaluated serial changes in the IL-17 serum levels after transplantation and compared the two study groups in this respect. In both allogeneic and syngeneic recipients, serum levels of IL-17 peaked on day 3 , which corresponded to grade $2 \mathrm{CMN}$ and grade $1 \mathrm{R}$ ACR $(308.0 \pm 74.9 \mathrm{pg} / \mathrm{ml}$ vs. $300.1 \pm$ $63.1 \mathrm{pg} / \mathrm{ml}$ for allogeneic and syngeneic recipients, respectively), and these values were significantly greater than in naïve B6 mice $(P<0.05)$. However, on day 5 , allogeneic recipients showed a sustained increase in IL-17 serum levels (285 \pm $16.6 \mathrm{pg} / \mathrm{ml}$ ), which contrasted significantly with that 
A

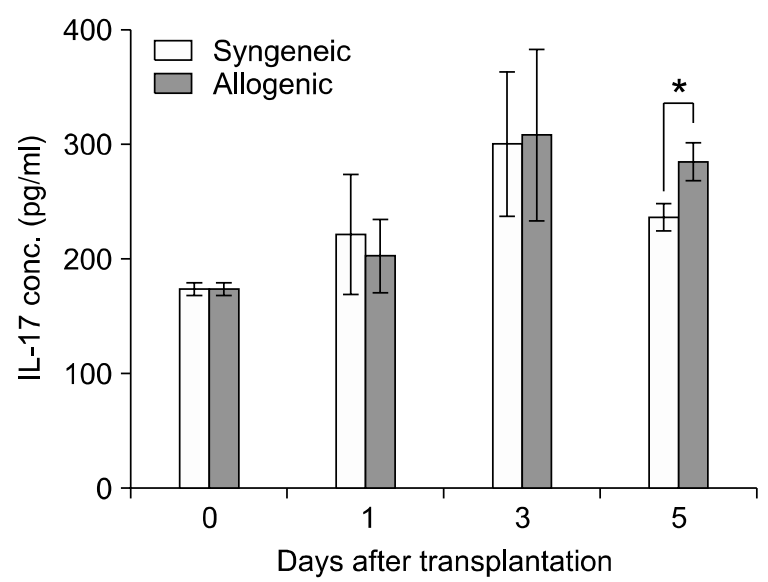

B

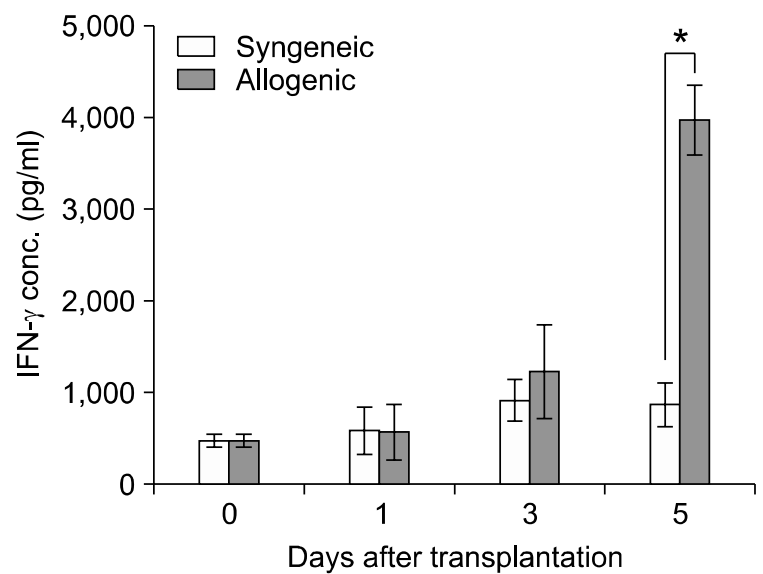

Figure 2. Changes in IL-17 and IFN- $\gamma$ serum levels. Circulating levels of IL-17 and IFN- $\gamma$ were quantified in mouse serum using BioPlex ${ }^{\circledR}$ Cytokine Assay kit. (A) IL-17 serum levels were peaked on the $3^{\text {rd }}$ postoperative day and then decreased in both groups. However, allogeneic recipients had continuously higher IL-17 levels on the $5^{\text {th }}$ postoperative day. (B) The serum levels of IFN- $\gamma$ were elevated on the $5^{\text {th }}$ postoperative day in allogeneic recipients. These changes in IL-17 serum levels suggest IL-17 production in vivo is associated with ischemic reperfusion injury during the early postoperative period and then accompanied by alloimmune responses during acute rejection. ${ }^{*} P<0.05$ between the two groups on specific postoperative days.

observed in syngeneic recipients $(236.1 \pm 11.9$ $\mathrm{pg} / \mathrm{ml})(P<0.05)$. As illustrated in Figure 2B, serum levels of IFN- $\gamma$ did not change significantly with time in syngeneic recipients $(P=n s)$. On the other hand, in allogeneic recipients, serum levels of IFN- $\gamma$ peaked on day 5 and showed significant elevations over other time points $(P<0.05)$. The results of this work led us to assume that IL-17 production in vivo is due to neutrophils contributing to ischemic reperfusion injury during the early postoperative period, which is then accompanied by alloimmune responses during acute rejection.

\section{Serial changes in the frequencies of $\mathrm{IL}-17^{+}$cells and Treg cells among splenocytes}

To evaluate this hypothesis, concerning the sequential evolution of IL-17 response after transplantation, we examined the phenotype of $\mathrm{IL}-17^{+}$splenocytes using flow cytometry. In agreement with our hypothesis, the frequencies of $\mathrm{Ly} 6 \mathrm{G}^{+} \mathrm{IL}-17^{+}$cells (Ly6G ${ }^{+} \mathrm{IL}-17^{+} / \mathrm{Ly} 6 \mathrm{G}^{+}$cells) peaked on day $3(2.94$ \pm 1.50 and $4.0 \pm 1.35 \%$, respectively for allogeneic and syngeneic recipients), and thereafter decreased in both groups (Figure $3 C, P<0.05$ ). The mean frequency of $\mathrm{Th} 17\left(\mathrm{CD} 4^{+} \mathrm{IL}-17^{+} / \mathrm{CD} 4^{+} \mathrm{T}\right.$ cells) in naïve $\mathrm{B} 6$ mice was $0.32 \pm 0.08 \%$ (Figure $3 A$ ). However, after cardiac transplantation, Th17 frequencies peaked on day 5 in allogeneic recipients $(P<0.05)$. Allogeneic recipients showed high $T_{h} 17$ frequencies on day $5(1.70 \pm 0.20 \%)$, which were significantly higher than Th17 frequencies in the syngeneic group at this time $(0.98 \pm$ $0.17)(P<0.05)$. Allogeneic recipients also showed significantly elevated $\mathrm{CD} 8^{+} \mathrm{IL}-17^{+} \mathrm{T}$ cell $\left(\mathrm{CD} 8^{+} \mathrm{IL}-17^{+} /\right.$ $\mathrm{CD} 8^{+} \mathrm{T}$ cells) frequencies on day 5 (Figure $3 \mathrm{~B}, P$ $<0.05)$. Furthermore, allogeneic recipients had a higher mean frequency of $\mathrm{CD} 8^{+} \mathrm{IL}-17^{+} \mathrm{T}$ cells on day $5(1.95 \pm 0.3 \%)$ than syngeneic recipients $(1.16 \pm 0.2 \%)(P=0.063)$.

Treg cells constituted $4.58 \pm 0.2 \%$ of $\mathrm{CD}^{+}{ }^{+} \mathrm{T}$ cells in naïve $\mathrm{B} 6$ mice. The frequencies of $\mathrm{Treg}$ cells $\left(\mathrm{CD}_{4}{ }^{+} \mathrm{CD} 25^{+} \mathrm{Foxp}^{+} / \mathrm{CD} 4^{+} \mathrm{T}\right.$ cells) increased progressively until day 5 in both syngeneic $(6.52 \pm 0.3 \%)$ and allogeneic $(6.19 \pm 0.6 \%)$ recipients (Figure 3D, $P<0.05)$. As shown in Figure $4, \mathrm{IL}-17$ producing $\mathrm{CD}^{+} \mathrm{T}$ cells were predominantly $\mathrm{CD} 4^{+} \mathrm{CD} 25^{+} \mathrm{T}$ cells. However, $\mathrm{CD} 4^{+} \mathrm{CD} 25^{+} \mathrm{T}$ cells were mostly negative for $\mathrm{IL}-17$, and $\mathrm{CD} 4^{+} \mathrm{CD} 25^{+} \mathrm{Foxp}^{+} \mathrm{IL}-17^{+} \mathrm{T}$ cells were virtually undetectable.

To ascertain whether the balance between proinflammatory $T_{h} 17$ and anti-inflammatory Treg is disrupted during acute rejection, the ratio of Th17 to Treg was evaluated. With progression of allograft rejection, allogeneic recipients had higher Th17/Treg ratios, i.e., allogeneic recipients had significantly higher Th17/Treg ratios on day 5 than on days 0 and 1 and also had significantly higher Th17/Treg ratios on day 5 than syngeneic recipients (Figure 5).

\section{Expression of IL-17 in graft-infiltrating cells}

To assess longitudinal changes in graft-infiltrating $\mathrm{IL}-17^{+}$cells after transplantation, we used double immunofluorescent staining and confocal analysis. It was found that neutrophils $\left(\mathrm{Ly} 6 \mathrm{G}^{+}\right.$; Figure $\left.6 \mathrm{~A}-\mathrm{C}\right)$, $\mathrm{CD} 4^{+} \mathrm{T}$ cells (Figure 6D-F), and $\mathrm{CD} 8^{+} \mathrm{T}$ cells 
A

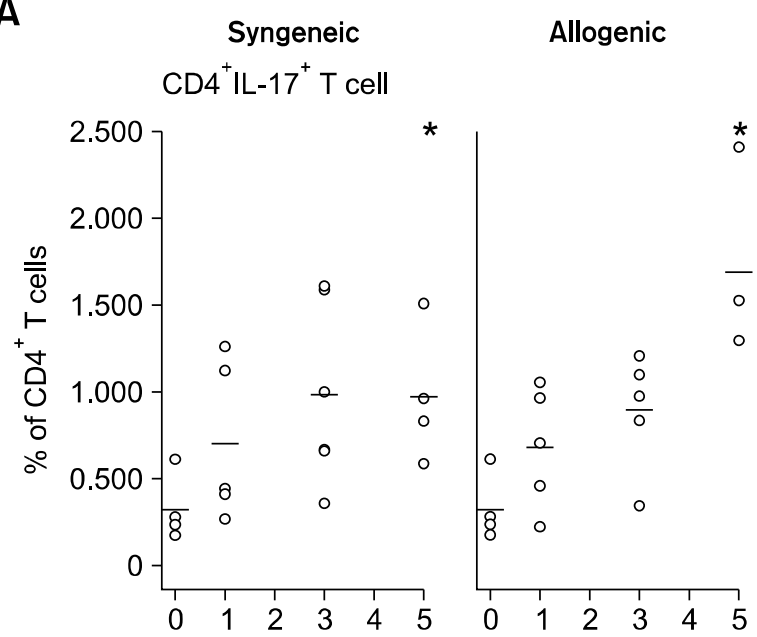

C $\quad$ Ly6G $^{+} \mathrm{IL}-17^{+}$cell

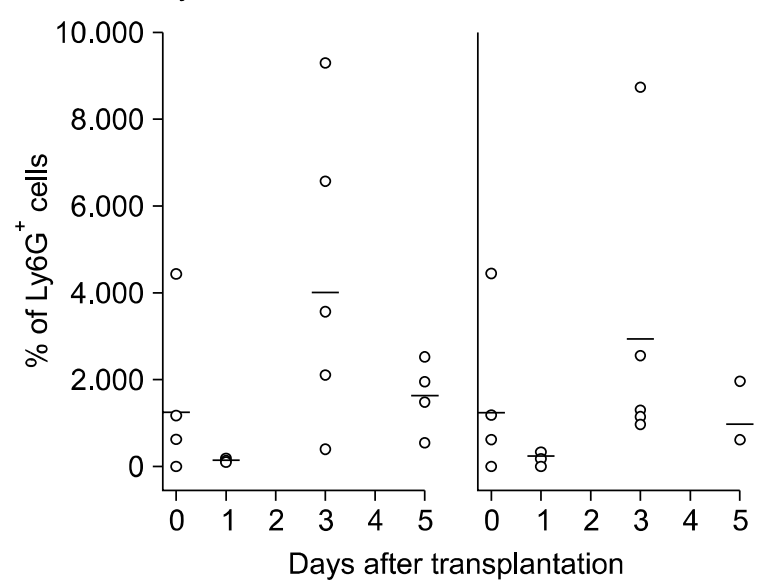

B

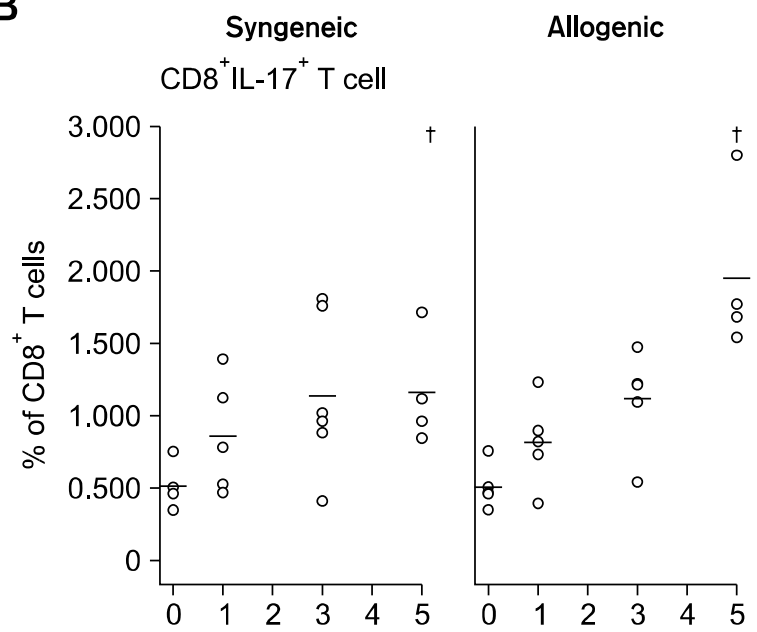

D $\quad \mathrm{CD}^{+} \mathrm{CD} 25^{+} \mathrm{Foxp}^{+} \mathrm{T}$ cell

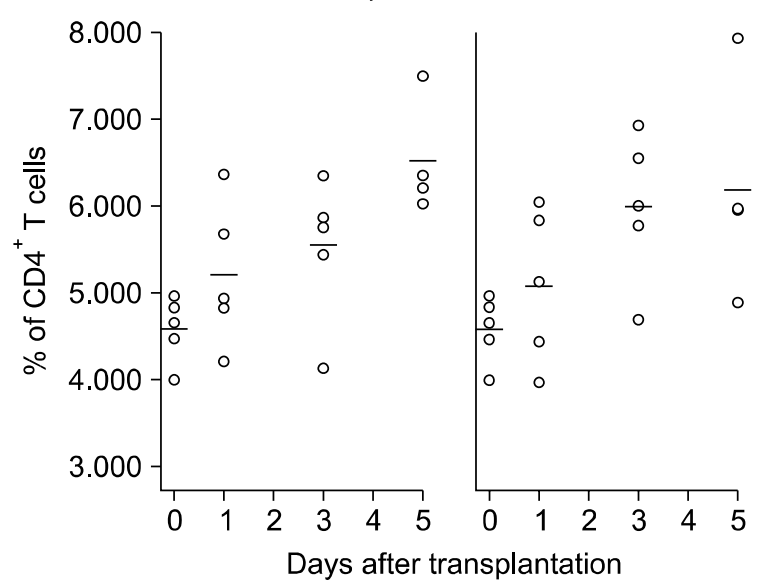

Figure 3. Flow cytometric analysis of splenocytes after syngeneic or allogeneic murine cardiac transplantations. The frequencies of $\mathrm{CD} 4^{+} \mathrm{IL}-17^{+} \mathrm{T}(\mathrm{Th} 17)$ cells and $C D 8^{+} I L-17^{+}$T cells peaked on day 5 in allogeneic recipients $(A, B)$ whereas Ly $6 \mathrm{G}^{+} \mathrm{IL}-17^{+}$cells peaked on day 3 in both syngeneic and allogeneic recipients $(\mathrm{C})$. The frequencies of $\mathrm{CD} 4^{+} \mathrm{CD} 25^{+}$Foxp3 ${ }^{+} \mathrm{T}$ (Treg) cells increased gradually in both groups (D). ${ }^{*} P<0.05$ and ${ }^{\dagger} P<0.10$ between the two groups on specific days.

(Figure 6G-I) were IL-17-positive. In both syngeneic and allogeneic grafts, Ly6G ${ }^{+}$cells highly expressed IL-17 during the early postoperative period. In allogeneic grafts, on days 3 and $5,13.1 \pm 1.3 \%$ and $9.3 \pm 1.2 \%$ of graft-infiltrating $\mathrm{Ly} 6 \mathrm{G}^{+}$cells expressed IL-17, respectively. Likewise, in syngeneic grafts, $12.3 \pm 1.1 \%$ and $5.9 \pm 0.5 \%$ of graft-infiltrating Ly $6 \mathrm{G}^{+}$cells expressed IL-17. Graftinfiltrating $\mathrm{Th}_{\mathrm{h}} 17$ and $\mathrm{CD} 8^{+} \mathrm{IL}-17^{+} \mathrm{T}$ cells were identified only in allografts. Th17 cells $(9.1 \pm 1.3 \%$ of $\mathrm{CD}^{+} \mathrm{T}$ cells) were demonstrated only on day 3 , which corresponded to early acute rejection. In accord with our flow cytometry results, $\mathrm{CD}^{+}$as well as $\mathrm{CD}^{+}{ }^{+} \mathrm{T}$ cells labeled for IL-17 during the acute rejection period. $\mathrm{CD}^{+} \mathrm{T}$ cells expressed IL-17 on day $3(13.3 \pm 0.9 \%)$ and day $5(11.7 \pm 1.9 \%)$. Table 1 summarized the longitudinal changes in the absolute cell counts of $\mathrm{Ly}_{6 \mathrm{G}}{ }^{+}$cells, $\mathrm{CD} 4^{+} \mathrm{T}$ cells and $\mathrm{CD}^{+} \mathrm{T}$ cells and the percentages of $\mathrm{IL}-17^{+}$ cells in each cell type.

\section{Discussion}

The role of $T_{h} 1$ and $T_{h} 2$ cells in acute allograft rejection has been widely investigated and the Th1/Th2 model has been used as a framework to explain the mechanism involved. Increased production of IFN- $\gamma$, a prototypic cytokine of Th1 response, and mononuclear cell infiltration of the graft are commonly associated with acute allograft rejection. Thus, $\mathrm{Th} 1$ cells are generally considered to be the main mediators of allograft rejection (Chan et al., 1995). On the other hand, Th2 cells 
Table 1. Absolute cell counts of $\mathrm{Ly}_{6 \mathrm{G}}{ }^{+}$cells, $\mathrm{CD} 4^{+} \mathrm{T}$ cells and $\mathrm{CD} 8^{+} \mathrm{T}$ cells and percentages of $\mathrm{IL}-17^{+}$cells in each cell type.

\begin{tabular}{lcccccc}
\hline & \multicolumn{2}{c}{ Day 3} & & \multicolumn{2}{c}{ Day 5 } \\
\cline { 2 - 3 } \cline { 5 - 6 } & Syngeneic & Allogeneic & & Syngeneic & Allogeneic \\
\hline Ly6G $^{+}$cell No $\left(\mathrm{mm}^{-2}\right)$ & $754 \pm 110$ & $1,081 \pm 220$ & & $480 \pm 108$ & $680 \pm 34$ \\
Ly6G $^{+} \mathrm{IL}-17^{+}(\%)$ & $12.3 \pm 1.1$ & $13.1 \pm 1.3$ & & $5.9 \pm 0.5$ & $9.3 \pm 1.2$ \\
$\mathrm{CD}^{+}$cell No $\left(\mathrm{mm}^{-2}\right)$ & $375 \pm 56$ & $1,030 \pm 117$ & & $128 \pm 61$ & $1,503 \pm 372$ \\
$\mathrm{CD}^{+} \mathrm{IL}-17^{+}(\%)$ & - & $9.1 \pm 1.3$ & & - & - \\
$\mathrm{CD} 8^{+}$cell No $\left(\mathrm{mm}^{-2}\right)$ & $343 \pm 74$ & $1,194 \pm 182$ & & $113 \pm 43$ & $1,900 \pm 101$ \\
$\mathrm{CD} 8^{+} \mathrm{IL}-17^{+}(\%)$ & - & $13.3 \pm 0.9$ & & - & $11.7 \pm 1.9$ \\
\hline
\end{tabular}

Longitudinal changes in graft-infiltrating cells after transplantation were assessed with double immunofluorescent staining and confocal analysis. With progression of rejection, allografts showed the relative predominance of $\mathrm{CD} 8^{+} \mathrm{T}$ cells.

were initially predicted to promote unresponsiveness and to be associated with the induction of transplant tolerance. However, Th2-mediated rejection has been also reported to be involved in allograft rejection through graft infiltration by eosinophils, especially under conditions in which IFN- $\gamma$ is depleted (Martinez et al., 1993; Bishop et al.,

A

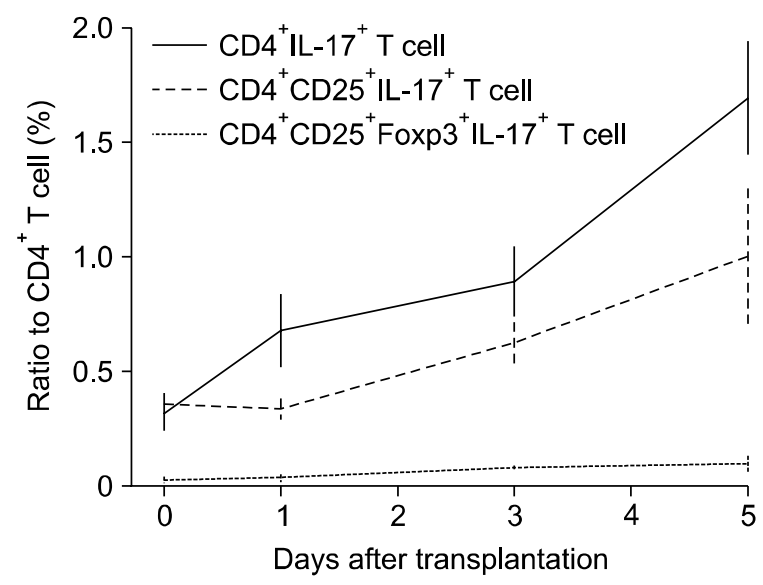

C

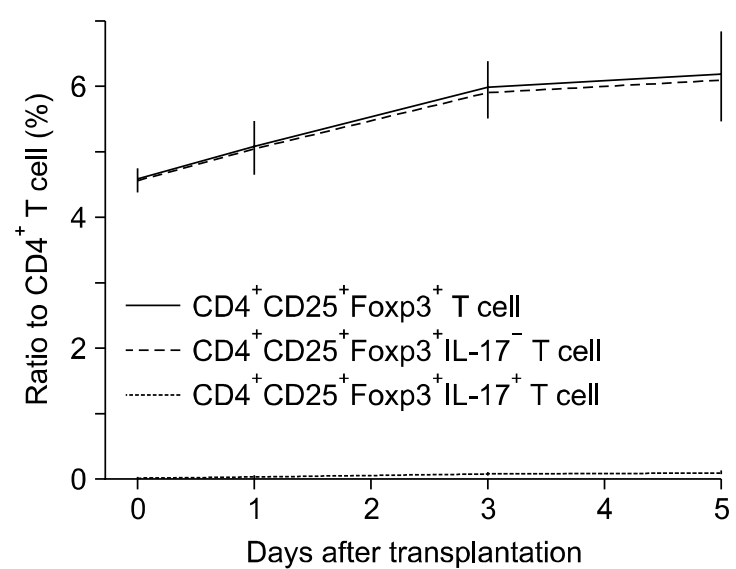

2001). However, this $T_{h} 1 / T_{h} 2$ paradigm has been recently challenged by the finding that $\mathrm{IL}-17$ is associated with allograft rejection, which suggests that Th17 may participate in transplant immunity (Van Kooten et al., 1998; Tang et al., 2001; Loong et al., 2002; Li et al., 2006). Furthermore, it has been reported that $\mathrm{IL}-17$ is produced by $\mathrm{Th} 17$,

B

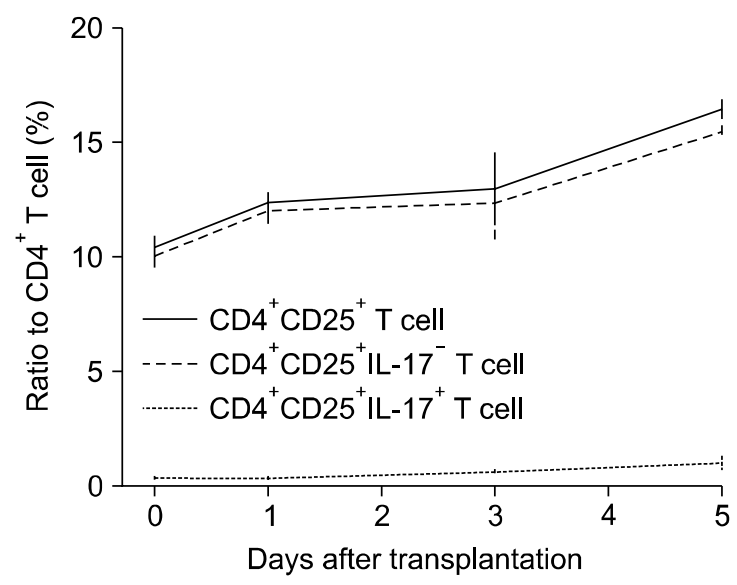

Figure 4. Treg cells scarcely produced IL-17 in allogeneic murine cardiac transplant recipients. (A) More than $60 \%$ of $\mathrm{CD}^{+} \mathrm{IL}-17^{+} \mathrm{T}$ cells were $\mathrm{CD}^{+} \mathrm{CD} 25^{+} \mathrm{IL}-17^{+} \mathrm{T}$ cells. (B, C) but fewer than $5 \%$ of $\mathrm{CD} 4^{+} \mathrm{CD} 25^{+} \mathrm{T}$ cells and fewer than $2 \%$ of $C D 4^{+} \mathrm{CD}^{+} 5^{+} \mathrm{Foxp}^{+} \mathrm{T}$ cells produced IL- 17 . 


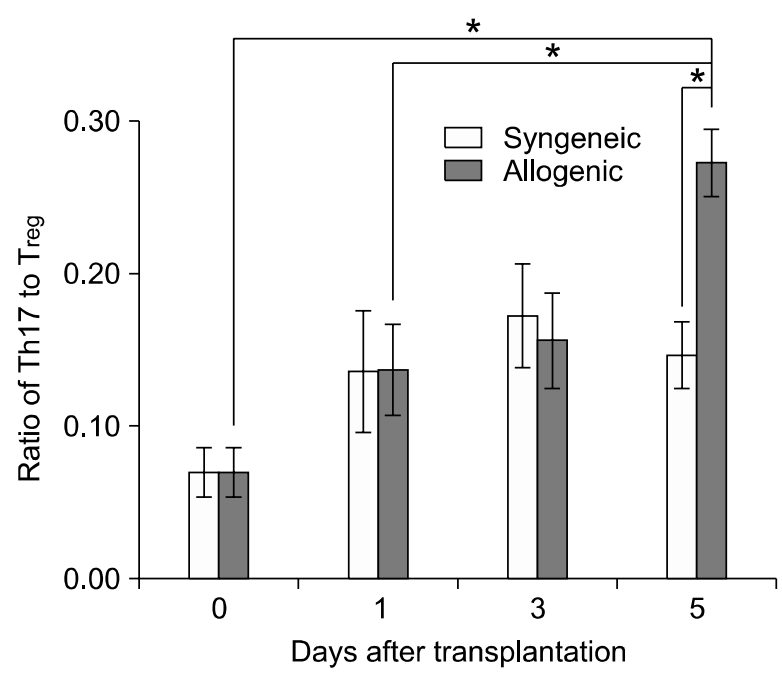

Figure 5. The Th17/Treg balance was disrupted with progression of allogeneic cardiac graft rejection. The ratio of Th17 to Treg cells were calculated using flow cytometric data of splenocytes in syngeneic and allogeneic murine cardiac transplant recipients. Allogeneic recipients showed

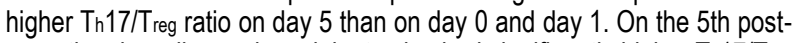
operative day, allogeneic recipients also had significantly higher $T_{h} 17 / T_{\text {reg }}$ ratios than syngeneic recipients. ${ }^{*} P<0.05$.

natural killer, natural killer T, $\gamma \delta \mathrm{T}$, and $\mathrm{CD} 8^{+} \mathrm{T}$ cells, and even by neutrophils (Kryczek et al., 2007; Weaver et al., 2007; Hoshino et al., 2008). Yuan and colleagues reported that CD4Th17 cells mediate accelerated vascular rejection and vasculopathy in $\mathrm{T}^{- \text {bet }^{-/}}$mice which exhibit profound deficiency in Th1 response (Yuan et al., 2008). Thus, it would appear that the cellular source of IL-17 and the dynamics of IL-17-producing cells should be investigated in a wild-type transplantation model without pre-conditioning.

In the present study, we initially evaluated changes in IL-17 serum levels after cardiac transplantation in syngeneic and allogeneic recipients. In agreement with previous studies (Hsieh et al., 2001; Loong et al., 2002), we found that the serum level of IL-17 peaked on day 3 and declined thereafter in both recipient types (Figure $2 \mathrm{~A}$ ). However, on day 5, allogeneic recipients showed a continuously increased serum level of IL-17 whereas syngeneic recipients did not. This finding suggests that $\mathrm{IL}-17$ is produced by innate immunity during the early postoperative period, and that $\mathrm{IL}-17$ production is enhanced by allogeneic immunity during allograft rejection. To confirm this hypothesis, we analyzed the phenotype of IL-17 $7^{+}$splenocytes by flow cytometry. On day $3, \mathrm{Ly}_{6 \mathrm{G}}{ }^{+}$cells were found to express IL-17 highly in both syngeneic and allogeneic recipients. However, on day 5, in contrast to syngeneic recipients, allogeneic recipients showed a high proportion of $\mathrm{Th} 17$ and $\mathrm{CD} 8^{+} \mathrm{IL}-17^{+} \mathrm{T}$ cells
(Figure 3). Interestingly, IL-17 expression was comparable in $\mathrm{CD}^{+}$and $\mathrm{CD}^{+} \mathrm{T}$ cells in allogeneic recipients. Thus, our findings lead us to conclude that neutrophils that contribute to ischemic reperfusion injury produce mainly IL-17 during the early postoperative period and that $\mathrm{CD}^{+}$as well as $\mathrm{CD}^{+}{ }^{+} \mathrm{T}$ cells secrete $\mathrm{IL}-17$ during acute allograft rejection due to an adaptive immune response.

The second important finding of the present study arose from double-labeling confocal analysis. Specifically, IL $-17^{+}$cells were found to contain a rather higher proportion of $\mathrm{Ly}_{6 \mathrm{G}}{ }^{+}, \mathrm{CD} 4^{+}$and $\mathrm{CD} 8^{+}$ $\mathrm{T}$ cells in grafts (up to $15 \%$ ) than in spleen, which may have been due to the in vivo microenvironment. Similar results have been reported by Tzartos et al. (2008) in a study on multiple sclerosis (MS) in which $\mathrm{IL}-17^{+} \mathrm{T}$ cells were found to be associated with increased activity in MS lesion, and reported by Korn et al. (2007) in an experimental allergic encephalitis model, in which $\mathrm{IL}-17^{+}$cells were detected in the inflamed CNS, but not in the draining lymph nodes. In the present study, CD8 ${ }^{+} \mathrm{IL}-17^{+} \mathrm{T}$ cells were identified for up to 5 days in allografts after cardiac transplantation, whereas $\mathrm{Th} 17$ cells were detected only on day 3 (Table 1). This contradicts an observation by Langrish et al. (2005) that IL- $17^{+}$cells were mainly composed of $\mathrm{CD}^{+} \mathrm{T}$ cells in an EAE model. This apparent difference may be due to the relative predominance of $\mathrm{CD}^{+} \mathrm{T}$ cells during cardiac allograft rejection (Burrell et al., 2008).

It has been reported that there is a dichotomy in the generation of $\mathrm{Th} 17$ that induces autoimmunity and Treg that inhibits autoimmune tissue injury (Bettelli et al., 2006; Mucida et al., 2007). Thus, the balance between Th17 and Treg cells may be important in induction or regulation of tissue inflammation. This leads to the third major finding of the present study; we demonstrated for the first time that $\mathrm{Th} 17 / \mathrm{T}$ reg balance is disrupted during allograft rejection. We observed that the frequencies of Th17 (Figure 3A) and Treg cells (Figure 3D) among $\mathrm{CD}^{+}{ }^{+} \mathrm{T}$ cells gradually and concomitantly increased after cardiac transplantation in both allogeneic and syngeneic recipients, but that the Th17/Treg ratio on day 5 was significantly higher in allogeneic than in syngeneic recipients (Figure 5). This suggests that the disruption of the balance between Th17 and Treg is associated with the development of allograft rejection, as well. Similarly, Cheng et al. (2008) also found that a Th17/Treg functional imbalance exists in patients with acute coronary syndrome (including unstable angina and acute myocardial infarction).

Finally, Benghiat et al. (2008) reported that Th17 cells could be part of $\mathrm{CD}^{2} 5^{+}$memory $\mathrm{T}$ cells and 

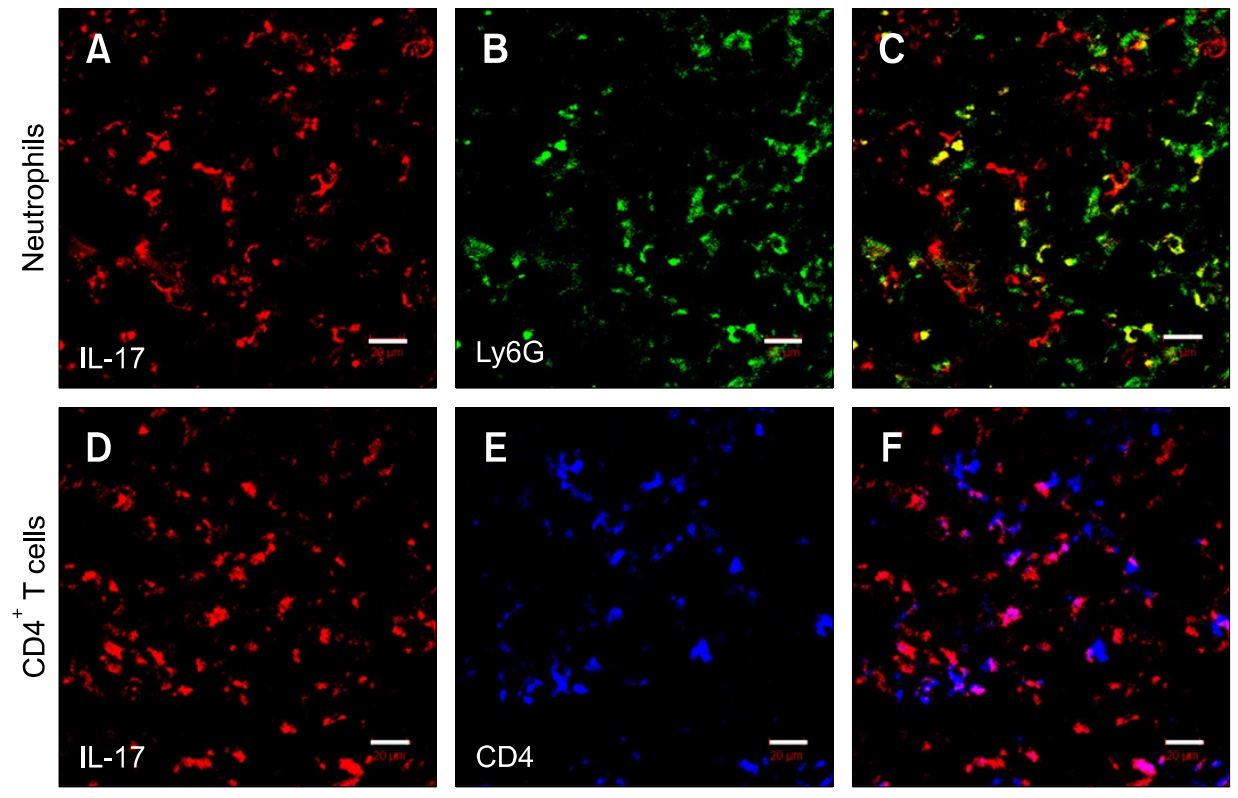

Figure 6. IL-17 production during murine cardiac transplant rejection. Double-immunofluorescence staining confocal microscopy images. Micrographs of staining for IL-17 (A, $D$ and $G$; red), Ly6G (B; neutrophils, green), CD4 (E; blue) and CD8 (H; digitally converted to blue) in active inflammatory areas of a allogeneic murine cardiac transplant on the $3^{\text {rd }}$ postoperative day. Overlays demon-
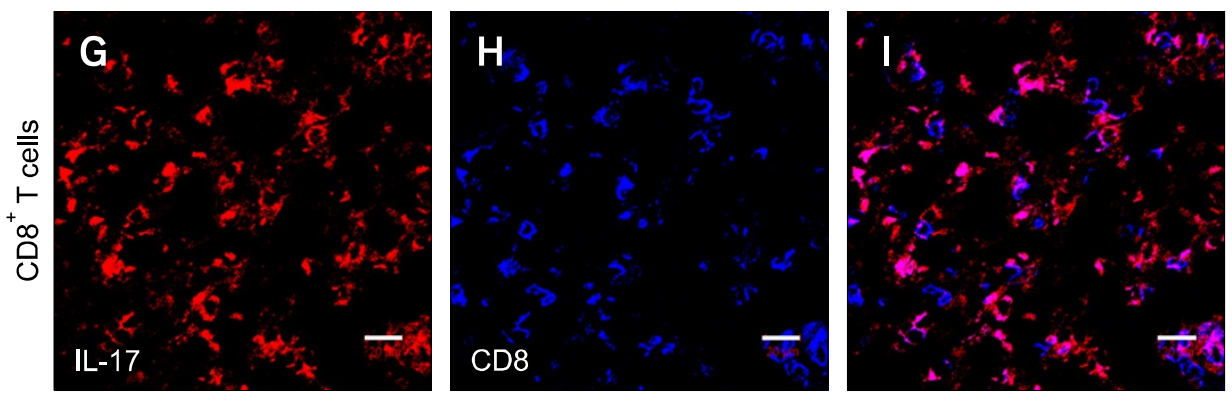
strate IL-17 expression in neutrophils ( $\mathrm{C}$; yellow), $\mathrm{CD} 4^{+} \mathrm{T}$ cells ( $\mathrm{F}$; pink), and $\mathrm{CD}^{+} \mathrm{T}$ cells (l; pink). Ly $6 \mathrm{G}^{+} \mathrm{IL}-17^{+}$cells were observed at 3 and 5 days postoperatively in both syngeneic and allogeneic cardiac grafts. $C D 4^{+} I L-17^{+} T\left(T_{h} 17\right)$ cells were present only at 3 day postoperatively in cardiac allografts and $\mathrm{CD} 8^{+} \mathrm{IL}-17^{+} \mathrm{T}$ cells were observed on days 3 and 5 in allogeneic cardiac grafts. Scale bar $=20 \mu \mathrm{m}$.

that isolation of $n$ Tregs solely on CD25 expression may lead to undesired selection of them. Likewise, in the present study, a considerable amount of Th17 cells were found to be positive for CD25, which is also a marker for activated T cells, whereas Foxp3 ${ }^{+}$ Tregs were found to scarcely express IL-17 (Figure 4). However, as $\mathrm{CD} 4^{+} \mathrm{CD} 25^{+} \mathrm{Foxp} 3^{+}$regulatory $\mathrm{T}$ cells can induce $\mathrm{CD}^{+} \mathrm{CD} 25-\mathrm{Foxp}^{-} \mathrm{T}$ cells to become Th17 cells and can differentiate into $\mathrm{Th}_{\mathrm{h}} 17$ cells (Xu et al., 2007), close attention should be paid to the selection of Tregs and also to the development of the Th17 responses during Tregs-based immunotherapy.

Altogether, the present study demonstrates the dynamic differentiation of IL-17-producing cells, including $\mathrm{Ly} 6 \mathrm{G}^{+}$(neutrophils), $\mathrm{CD4}^{+}$and $\mathrm{CD} 8^{+} \mathrm{T}$ cells in the context of allograft rejection, in a wild-type murine cardiac transplant model. We found that neutrophils produce IL-17 during the early postoperative period and that $\mathrm{CD} 8^{+}$as well as $\mathrm{CD}^{+}{ }^{+} \mathrm{T}$ cells produce $\mathrm{IL}-17$ during allograft rejection. In addition, our findings also demonstrate that $\mathrm{IL}-17^{+}$cells contain higher proportions of Ly6G ${ }^{+}$cells, $\mathrm{CD}^{+}$and $\mathrm{CD} 8^{+} \mathrm{T}$ cells in cardiac grafts than in spleens. Finally, $\mathrm{Th}_{\mathrm{h}} 17 / \mathrm{T}$ reg ratios were found to be significantly higher during allograft rejection, which suggests that Th17 to Treg imbalance plays a role in the development of allograft rejection. To draw firm conclusion, however, it needs an allograft transplantation model where only some of the recipients accept the graft. The Th17/Treg balances between allogeneic acceptor and rejector groups would be compared to test whether the balance is disrupted in the rejector group.

In spite of an observational study, this study would provide basic information on Th17 biology in transplant immunity, which needs further investigation.

\section{Methods}

\section{Mice}

Female C57BL/6 (B6, H-2b) and BALB/C (H-2d) mice were purchased from Japan SLC (Kotoh-cho, Japan), and housed in a specific pathogen-free animal facility. Mice were routinely used at about 8 weeks of age. This study was approved by Institutional Animal Care and Use 
Committee (IACUC) of the Clinical Research Institute at Seoul National University Hospital. This facility is accredited by the Association for the Assessment and Accreditation of Laboratory Animal Care International.

\section{Heterotopic cardiac transplantation}

For allogeneic transplantations, BALB/C and B6 mice were used as donors and recipients (the allogeneic group), respectively, and for syngeneic transplantations group, B6 mice were used as donors and recipients (the syngeneic group). Heterotopic cardiac transplantations were performed with microsurgical technique in a similar manner as previously described (Corry et al., 1973; Niimi, 2001). Briefly, donor hearts were harvested after cool perfusion with heparinized lactated Ringer's solution and then placed into cooled lactated Ringer's solution while the recipients were prepared for transplantation. The graft aorta was anastomosed to the recipient abdominal aorta and the graft pulmonary artery was anastomosed to the recipient inferior vena cava. Effective ventricular contraction usually occurred within $30 \mathrm{~s}$ after reperfusion.

\section{Histology}

Cardiac grafts were recovered at several time points after transplantation, fixed in formalin, paraffin embedded, serially sectioned at $4 \mu \mathrm{m}$, and stained with H\&E by routine technique. At least two separate slides were examined to assess myocyte viability and acute rejection. The extent of coagulative myocyte necrosis (CMN), which is the most definitive manifestation of ischemic myocyte injury, was graded semiquantitatively (Fyfe et al., 1996; Tan et al., 2007): grade 0 , no evidence of CMN; grade 1, mild (focal) CMN; grade 2, moderate (multifocal) $\mathrm{CMN}$; and grade 3, severe (confluent) CMN. Acute cellular rejection (ACR) was graded according to the criteria proposed by the International Society for Heart and Lung Transplantation (ISHLT) (Stewart et al., 2005), as follows: grade 1R, mild ACR; grade 2R, moderate ACR; and grade $3 R$, severe $A C R$, regardless of the presence or absence of $C M N$ on slides. All the slides were examined by single pathologist.

\section{Cytokine levels}

Circulating levels of IL-17 and IFN- $\gamma$ were quantified in mouse serum using the Bio-Plex ${ }^{\circledR}$ Cytokine Assay 18-Plex kit (BioRad Laboratories, Hercules, CA) and the Bio-Plex 200 platform, according to the manufacturer's instructions.

\section{Flow cytometry analysis}

Spleens were retrieved, mashed, and then erythrocytes were lysed using an RBC lysing buffer. Splenocytes were first stained extracellularly with anti-mouse CD3 APC, anti-mouse CD4 PE, anti-mouse CD8 PECy7, anti-mouse CD25 PECy7, anti-mouse CD45 APC, anti-mouse Ly6G $\mathrm{PE}$, and appropriate isotype control $\mathrm{mAb}$ (BD Pharmingen, San Jose, CA), as per manufacturer's instructions. After surface staining, cells were fixed and permeabilized with Fixation/Permeabilization solution (BD Pharmingen), and then stained intracellularly with anti-mouse IL-17 FITC and anti-mouse Foxp3 APC (eBioscience, San Diego, CA), according to the manufacturer's protocol. Cell analysis was performed using a FACScan cytometer equipped with CellQuest software (BD Bioscience).

\section{Immunofluorescent staining and confocal analysis}

For immunostaining, cardiac grafts were recovered at several time points after transplantation and embedded in OCT compound (Sakura Finetechnical Co., Tokyo, Japan), and then snap-frozen in liquid nitrogen. Frozen sections (4 $\mu \mathrm{m})$ were fixed in acetone for $10 \mathrm{~min}$ and air-dried. Slides were stained with anti-mouse Ly6G Alexa 647 (BioLegend, San Diego, CA), anti-mouse CD4 Pacific Blue, anti-mouse CD8 Alexa 488 (BD Pharmingen), and anti-mouse IL-17 PE (eBioscience) for direct immunofluorescent staining, and then analyzed with a LSM 5 Image Browser using an LSM 510 META confocal laser scanning microscope (Zeiss, Jena, Germany). Areas which showed the most extensive infiltration of inflammatory cells were selected and images were acquired at high-power $(\times 400)$ using a confocal microscope. The $\mathrm{CD} 4^{+}, \mathrm{CD}^{+}, \mathrm{Ly}_{6 \mathrm{G}}{ }^{+}$, and $\mathrm{IL}-17^{+}$ cells were counted in each image using ImageJ software (National Institutes of Health, Bethesda, MD). The percentages of $\mathrm{IL}-17^{+}$cells with respect to $\mathrm{CD} 4^{+}, \mathrm{CD} 8^{+}$, and $\mathrm{Ly} \mathrm{G}^{+}$cells were calculated using double immunofluorescent data. A second 'blind' observer re-determined percentages using the same images.

\section{Statistical analysis}

Statistical analysis was performed using SPSS software version 15.0 for Windows (SPSS, IL). Data are presented as mean \pm SEM and analyzed using the Mann-Whitney and Kruskal-Wallis tests. A $P$ value $<0.05$ was considered to be statistically significant.

\section{Acknowledgements}

We would like to thank Si Hwa Kim and Yu Jin Jung for their excellent microsurgical assistance and technical support. This work was supported by a research grant from the Clinical Research Institute (CRI), Seoul National University Hospital (\#0620082780).

\section{References}

Abbas AK, Murphy KM, Sher A. Functional diversity of helper T lymphocytes. Nature 1996;383:787-93

Aggarwal S, Ghilardi N, Xie MH, de Sauvage FJ, Gurney AL. Interleukin-23 promotes a distinct CD4 $\mathrm{T}$ cell activation state characterized by the production of interleukin-17. J Biol Chem 2003;278:1910-4

Amadi-Obi A, Yu CR, Liu X, Mahdi RM, Clarke GL, Nussenblatt RB, Gery I, Lee YS, Egwuagu CE. Th17 cells contribute to uveitis and scleritis and are expanded by IL-2 and inhibited by IL-27/STAT1. Nat Med 2007;13:711-8

Benghiat FS, Craciun L, De Wilde V, Dernies T, Kubjak C, Lhomme F, Goldman M, Le Moine A. IL-17 production elicited 
by allo-major histocompatibility complex class II recognition depends on CD25posCD4pos T cells. Transplantation 2008; 85:943-9

Bettelli E, Carrier Y, Gao W, Korn T, Strom TB, Oukka M, Weiner HL, Kuchroo VK. Reciprocal developmental pathways for the generation of pathogenic effector Th17 and regulatory T cells. Nature 2006;441:235-8

Bishop DK, Chan Wood S, Eichwald EJ, Orosz CG. Immunobiology of allograft rejection in the absence of IFN-gamma: CD8+ effector cells develop independently of CD4+ cells and CD40-CD40 ligand interactions. J Immunol 2001;166:3248-55

Burrell BE, Csencsits K, Lu G, Grabauskiene S, Bishop DK. CD8+ Th17 mediate costimulation blockade-resistant allograft rejection in T-bet-deficient mice. J Immunol 2008; 181:3906-14

Chan SY, DeBruyne LA, Goodman RE, Eichwald EJ, Bishop DK. In vivo depletion of CD8+ T cells results in Th2 cytokine production and alternate mechanisms of allograft rejection. Transplantation 1995;59:1155-61

Cheng X, Yu X, Ding YJ, Fu QQ, Xie JJ, Tang TT, Yao R, Chen $\mathrm{Y}$, Liao $\mathrm{YH}$. The Th17/Treg imbalance in patients with acute coronary syndrome. Clin Immunol 2008;127:89-97

Cho ML, Jung YO, Kim KW, Park MK, Oh HK, Ju JH, Cho YG, Min JK, Kim SI, Park SH, Kim HY. IL-17 induces the production of IL-16 in rheumatoid arthritis. Exp Mol Med 2008;40:237-45.

Corry RJ, Winn HJ, Russell PS. Primarily vascularized allografts of hearts in mice. The role of $\mathrm{H}-2 \mathrm{D}, \mathrm{H}-2 \mathrm{~K}$, and non-H-2 antigens in rejection. Transplantation 1973;16: 343-50

Cua DJ, Sherlock J, Chen Y, Murphy CA, Joyce B, Seymour B, Lucian L, To W, Kwan S, Churakova T, Zurawski S, Wiekowski M, Lira SA, Gorman D, Kastelein RA, Sedgwick JD. Interleukin-23 rather than interleukin-12 is the critical cytokine for autoimmune inflammation of the brain. Nature 2003;421:744-8

Dieckmann D, Bruett CH, Ploettner H, Lutz MB, Schuler G. Human CD4(+)CD25(+) regulatory, contact-dependent T cells induce interleukin 10-producing, contact-independent type 1-like regulatory T cells [corrected]. J Exp Med 2002; 196:247-53

Fontenot JD, Gavin MA, Rudensky AY. Foxp3 programs the development and function of CD4+CD25+ regulatory T cells. Nat Immunol 2003;4:330-6

Fujino S, Andoh A, Bamba S, Ogawa A, Hata K, Araki Y, Bamba T, Fujiyama Y. Increased expression of interleukin 17 in inflammatory bowel disease. Gut 2003;52:65-70

Fyfe B, Loh E, Winters GL, Couper GS, Kartashov Al, Schoen FJ. Heart transplantation-associated perioperative ischemic myocardial injury. Morphological features and clinical significance. Circulation 1996;93:1133-40

Homey B. [After Th1/Th2 now comes Treg/Th17: significance of Thelper cells in immune response organization]. Hautarzt 2006;57:730-2

Hoshino A, Nagao T, Nagi-Miura N, Ohno N, Yasuhara M,
Yamamoto K, Nakayama T, Suzuki K. MPO-ANCA induces IL-17 production by activated neutrophils in vitro via classical complement pathway-dependent manner. J Autoimmun 2008;31:79-89

Hsieh HG, Loong CC, Lui WY, Chen A, Lin CY. IL-17 expression as a possible predictive parameter for subclinical renal allograft rejection. Transpl Int 2001;14:287-98

Korn T, Bettelli E, Gao W, Awasthi A, Jager A, Strom TB, Oukka M, Kuchroo VK. IL-21 initiates an alternative pathway to induce proinflammatory $\mathrm{T}(\mathrm{H}) 17$ cells. Nature 2007; 448:484-7

Kotake S, Udagawa N, Takahashi N, Matsuzaki K, Itoh K, Ishiyama S, Saito S, Inoue K, Kamatani N, Gillespie MT, Martin TJ, Suda T. IL-17 in synovial fluids from patients with rheumatoid arthritis is a potent stimulator of osteoclastogenesis. J Clin Invest 1999;103:1345-52

Kryczek I, Wei S, Zou L, Altuwaijri S, Szeliga W, Kolls J, Chang A, Zou W. Cutting edge: $T_{h} 17$ and regulatory T cell dynamics and the regulation by IL-2 in the tumor microenvironment. J Immunol 2007; 178:6730-3

Langrish CL, Chen Y, Blumenschein WM, Mattson J, Basham B, Sedgwick JD, McClanahan T, Kastelein RA, Cua DJ. IL-23 drives a pathogenic T cell population that induces autoimmune inflammation. J Exp Med 2005;201:233-40

Li J, Simeoni E, Fleury S, Dudler J, Fiorini E, Kappenberger L, von Segesser LK, Vassalli G. Gene transfer of soluble interleukin-17 receptor prolongs cardiac allograft survival in a rat model. Eur J Cardiothorac Surg 2006;29:779-83

Loong CC, Hsieh HG, Lui WY, Chen A, Lin CY. Evidence for the early involvement of interleukin 17 in human and experimental renal allograft rejection. J Pathol 2002;197: 322-32

Martinez OM, Ascher NL, Ferrell L, Villanueva J, Lake J, Roberts JP, Krams SM. Evidence for a nonclassical pathway of graft rejection involving interleukin 5 and eosinophils. Transplantation 1993;55:909-18

Mosmann TR, Coffman RL. Th1 and Th2 cells: different patterns of lymphokine secretion lead to different functional properties. Annu Rev Immunol 1989;7:145-73

Mucida D, Park Y, Kim G, Turovskaya O, Scott I, Kronenberg $\mathrm{M}$, Cheroutre $\mathrm{H}$. Reciprocal $\mathrm{Th} 17$ and regulatory $\mathrm{T}$ cell differentiation mediated by retinoic acid. Science 2007;317: 256-60

Ng WF, Duggan PJ, Ponchel F, Matarese G, Lombardi G, Edwards AD, Isaacs JD, Lechler RI. Human CD4(+)CD25(+) cells: a naturally occurring population of regulatory $T$ cells. Blood 2001;98:2736-44

Niimi M. The technique for heterotopic cardiac transplantation in mice: experience of 3000 operations by one surgeon. J Heart Lung Transplant 2001;20:1123-8

Sakaguchi S, Ono M, Setoguchi R, Yagi H, Hori S, Fehervari Z, Shimizu J, Takahashi T, Nomura T. Foxp3+ CD25+ CD4+ natural regulatory $T$ cells in dominant self-tolerance and autoimmune disease. Immunol Rev 2006;212:8-27

Stewart S, Winters GL, Fishbein MC, Tazelaar HD, Kobashigawa J, Abrams J, Andersen CB, Angelini A, Berry 
GJ, Burke MM, Demetris AJ, Hammond E, Itescu S, Marboe CC, McManus B, Reed EF, Reinsmoen NL, Rodriguez ER, Rose AG, Rose M, Suciu-Focia N, Zeevi A, Billingham ME. Revision of the 1990 working formulation for the standardization of nomenclature in the diagnosis of heart rejection. J Heart Lung Transplant 2005;24:1710-20

Tan CD, Baldwin WM, 3rd, Rodriguez ER. Update on cardiac transplantation pathology. Arch Pathol Lab Med 2007;131: 1169-91

Tang JL, Subbotin VM, Antonysamy MA, Troutt AB, Rao AS, Thomson AW. Interleukin-17 antagonism inhibits acute but not chronic vascular rejection. Transplantation 2001;72: 348-50

Tzartos JS, Friese MA, Craner MJ, Palace J, Newcombe J, Esiri MM, Fugger L. Interleukin-17 production in central nervous system-infiltrating $T$ cells and glial cells is associated with active disease in multiple sclerosis. Am J Pathol 2008;172:146-55

Van Kooten C, Boonstra JG, Paape ME, Fossiez F, Banchereau J, Lebecque S, Bruijn JA, De Fijter JW, Van Es
LA, Daha MR. Interleukin-17 activates human renal epithelial cells in vitro and is expressed during renal allograft rejection. J Am Soc Nephrol 1998;9:1526-34

Weaver CT, Hatton RD, Mangan PR, Harrington LE. IL-17 family cytokines and the expanding diversity of effector $T$ cell lineages. Annu Rev Immunol 2007;25:821-52

Xu L, Kitani A, Fuss I, Strober W. Cutting edge: regulatory T cells induce CD4+CD25-Foxp3- T cells or are self-induced to become Th17 cells in the absence of exogenous TGF-beta. J Immunol 2007;178:6725-9

Yuan X, Paez-Cortez J, Schmitt-Knosalla I, D'Addio F, Mfarrej B, Donnarumma M, Habicht A, Clarkson MR, lacomini J, Glimcher LH, Sayegh MH, Ansari MJ. A novel role of CD4 Th17 cells in mediating cardiac allograft rejection and vasculopathy. J Exp Med 2008;205:3133-44

Zheng Y, Danilenko DM, Valdez P, Kasman I, EasthamAnderson J, Wu J, Ouyang W. Interleukin-22, a $\mathrm{T}(\mathrm{H}) 17$ cytokine, mediates IL-23-induced dermal inflammation and acanthosis. Nature 2007;445:648-51 